Síntese: Revista de Filosofia adere a uma Licença

\title{
O DISCURSO ANTIESCRAVISTA DE EPIFANIO DE MOIRANS SOBRE OS TÍTULOS DE ESCRAVIDÃO *
}

\author{
The anti-slavery discourse of Epifanio de Moirans on slavery titles
}

Fernando Rodrigues Montes D’Oca **

Resumo: Durante a Escolástica Barroca, vários autores quinhentistas e seiscentistas escreveram sobre a escravidão negra, mas poucos se preocuparam em defender a liberdade dos escravos africanos. Dentre esses poucos, podemos citar Francisco José de Jaca OFMCap (1645-1689) e Epifanio de Moirans OFMCap (1644-1689), autores que elaboraram um radical e verdadeiro projeto antiescravista. $O$ objetivo deste estudo é apresentar algumas teses desse projeto antiescravista a partir da obra de Moirans - Servi liberi seu naturalis mancipiorum libertatis iusta defensio ("Servos livres ou justa defesa da liberdade natural dos escravos"), de 1682 - mediante a reconstituição do núcleo argumentativo em que o autor trata dos títulos de escravidão.

Palavras-chave: Epifanio de Moirans. Escravidão Negra. Títulos de escravidão.

Abstract: During Baroque Scholasticism, many authors of the $16^{\text {th }}$ and $17^{\text {th }}$ centuries wrote on Black slavery, but only a few were interested in defending the African slaves' liberty. Among these few authors, we can mention Francisco José de Jaca OFMCap (1645-1689) and Epifanio de Moirans OFMCap (1644-1689), authors who elaborated a radical and true antislavery project. The aim of this study is present some theses of this antislavery project from the Moirans' work

\footnotetext{
* Este trabalho é parte de uma pesquisa desenvolvida no Instituto Federal Sul-rio-grandense (Campus Sapiranga), no âmbito do projeto "Liberdade e justiça para os escravos africanos: um estudo sobre os discursos antiescravistas de autores ibéricos dos séculos XVI-XVII" (PE010715/111), projeto financiado pela Pró-reitoria de Pesquisa, Inovação e Pós-graduação. ** Doutor em Filosofia pela PUCRS. Professor do Instituto Federal Sul-rio-grandense, campus Sapiranga. Artigo recebido em 26/02/2016 e aprovado para publicação em 11/05/2016.
} 
- Servi liberi seu naturalis mancipiorum libertatis iusta defensio ("Free Slaves or Just Defense of the Natural Liberty of Slaves"), 1682 -, by means of a reconstitution of argumentative core where the author deals with the slavery titles.

Key-words: Epifanio de Moirans. Black Slavery. Slavery Titles.

\section{Introdução}

$\mathrm{N}$ o contexto da chamada Escolástica Barroca, além do grande debate sobre a escravidão indígena - que envolveu autores proeminentes como Francisco de Vitoria OP (1483/86-1542) e Bartolomé de Las Casas OP (1484-1566), para citar apenas alguns -, outro importante debate chamou a atenção dos intelectuais ibéricos quinhentistas e seiscentistas: o debate sobre a escravidão negra. Para ser mais exato, o debate sobre a licitude da escravização dos africanos e do tráfico de escravos.

Esse debate não teve a mesma amplitude que o debate sobre a escravidão indígena, tampouco tornou-se apaixonante, com defesas entusiasmadas como as de Las Casas. Esse debate não envolvia seres desconhecidos nem a aplicação de uma teoria filosófica à vida prática e, logo, a busca de correspondentes empíricos para os escravos naturais de que falara Aristóteles. Ao contrário dos índios descobertos, que foram motivo de grande estranhamento e discussão, os africanos eram conhecidos de portugueses e espanhóis, e já na condição de escravos durante o séc. XV. De outra parte, e este ponto é deveras importante, o debate sobre a escravidão negra não era sobre uma instituição que tinha mais existência teórica do que prática (como a escravidão natural), mas sobre uma instituição antiguíssima, praticada por diversos povos, relatada na Sagrada Escritura, praticamente incontestada pela ou não perturbante para a Filosofia, permitida pela Igreja, prevista pelo Direito Romano e Castelhano e estavelmente em vigor em muitos lugares do mundo: a instituição escravidão civil ou legal (servitus civilis/legalis). Em tese, esse debate era, pois, menos complexo. Não estava em questão apoiar ou condenar a escravidão legal, mas apenas analisar se ela era praticada com justiça. Mas embora isso fosse aparentemente simples, esse debate revestiu-se de complexidades por causa do odioso comércio de escravos que se estabeleceu e devido à necessidade de os cristãos agirem com justiça e consciência segura.

Excetuando-se autores como Vitoria e Las Casas, cujas posições sobre a escravidão negra, diferentemente de suas posições sobre a escravidão indígena, foram modestas e não chegaram a ocupar um papel de destaque na história das ideias sobre o tema ${ }^{1}$, admite-se que os primeiros autores

${ }^{1}$ Encontramos menções sobre a escravidão negra e o tráfico em correspondências de Vitoria
e Las Casas. No caso de Vitoria, trata-se de uma carta a Bernardino de Vique (VITORIA, F. 
que mencionaram algo substantivo, conquanto breve, sobre a escravidão negra foram: Domingo de Soto OP (1494-1560) - em De iustitia et iure (Salamanca 1553; liv. IV, q. 2, a. 2); Fernando Oliveira (1507-ca.1581) - Arte da guerra do mar (Coimbra 1555; parte I, cap. 4); Tomás de Mercado OP (1525-1575) - Tratos y contratos de mercaderes y tratantes (Salamanca 1569; liv. I, cap. 15), posteriormente denominada Summa de tratos y contratos (Sevilla 1571; liv. II, cap. 20); e também o jurista, ativo no México, Bartolomé Frías de Albornoz (ca.1520-ca.1573) - Arte de los contractos (Valencia 1573; liv. II, tít. 12; liv. III, tít. 4$)^{2}$. Não obstante, foram os autores da Companhia de Jesus que efetivamente escreveram sobre o tema, liderados por Luis de Molina SJ (1535-1600), que se ocupou extensivamente do mesmo em seu monumental De iustitia et iure (Cuenca 1593-1609; t. I, trat. 2, disp. 32-40). Após Molina, vários jesuítas trataram da escravidão negra, dentre os quais, para citar apenas alguns: Fernão Rebelo SJ (1546-1608) - em Opus de obligationibus iustitiae, religionis et caritatis (Lyon 1608; parte I, liv. I, q. 9-10); Tomás Sánchez SJ (1550-1610) - Consilia seu opuscula moralia (Lyon 1634; t. I, liv. I, cap. 1, dúvida 4); Alonso de Sandoval SJ (1576-1652) - Naturaleza, policía sagrada i profana, costumbres $i$ ritos, disciplina i catecismo evangélico de

Political Writings. Cambridge: CUP, 1991, p. 334s; cf.: HÖFFNER, J. La Ética Colonial Española del Siglo de Oro. Madrid: Cultura Hispánica, 1957, p. 461s; PAGDEN, A. The Fall of Natural Man. Cambridge: CUP, 1986, p. 334s; ANDRÉS-GALLEGO, J. La esclavitud en la América española. Madrid: Encuentro, 2005, p. 34). No caso de Las Casas, quando ainda jovem, trata-se de uma instrução favorável à importação de escravos à América, bem como uma memória dirigida ao jovem imperador Carlos V (cf. e.g.: HÖFFNER, J. La Ética Colonial..., op. cit., p. 228s; HANKE, L. The Spanish Struggle for Justice in the Conquest of America. Philadelphia: University of Pennsylvania Press, 1949, p. 60; SOUZA, J. Las Casas, Alonso de Sandoval e a defesa da escravidão negra. Topoi, v. 7, n. 12, p. 25-59, 2006, p. 26s). Las Casas, no entanto, mais tarde, dessa vez revendo sua posição da juventude, também menciona algo em sua Historia de las Indias - t. I, cap. 17-27; t. III, cap. 102.119 (cf.: ZAVALA, S. Por la senda hispana de la libertad. 2a ed. México-DF: Fondo de Cultura Económica, 1993, p. 95-100; JOSAPHAT, C. Las Casas - Todos os direitos para todos. São Paulo: Loyola, 2000, p.298-305; SOUZA, J. Las Casas..., op. cit., p. 31ss; ALONZO, M. From Slave Driver to Abolitionist: Bartolomé de Las Casas on African Slavery. Patristica et Mediaevalia, n. 36, p. 17-28, 2015, p. 24s) -, obra que, todavia, não chegou a ter grande repercussão no contexto dos sécs. XVI-XVII por só ter sido publicada em 1875.

2 Sigo aqui Davis (The Problem of Slavery in Western Culture. Oxford: OUP, 1966, p. 187-190), Boxer (A Igreja Militante e a Expansão Ibérica: 1440-1770. São Paulo: Companhia das Letras, 2007, p. 45-53), Vilar (La postura de la Iglesia frente a la esclavitud. Siglos XVI y XVII. In: SOLANO, F.; GUIMERÁ, A. (Eds.). Esclavitud y Derechos Humanos. Madrid: CSIC, 1986, p. 26s) e Andrés-Gallego (La esclavitud..., op. cit., p. 31-35), que mencionam esses autores como os primeiros a escreverem sobre a escravidão negra no contexto ibérico - cf. também: THOMAS, H. The Slave Trade. New York: Simon \& Schuster, 1997, p. 126s.146s; AÑOVEROS, J. Luis de Molina y la Esclavitud de los Negros Africanos en el siglo XVI. Revista de Indias, v. 60, n. 219, p. 307-329, 2000, p. 308; SARANYANA, J. La Filosofía Medieval. Pamplona: EUNSA, 2003, p. 483ss. Boxer e Vilar também mencionam Alonso de Montufar OP (1489-1572), que condenou a escravidão e o tráfico em carta enviada a Felipe II, em 1560. Meu propósito primeiro, aqui, porém, é apenas informar brevemente, e sem pretensão de ser exaustivo, os principais autores que se posicionaram sobre a escravidão negra em obras e tratados na época. Trabalhar com correspondências é algo que extrapola meu objetivo e que demandaria um estudo específico. 
todos etíopes (Sevilla 1627), mais conhecida, porém, como De instauranda Æthiopum salute, título que só foi estabelecido na segunda edição (Madrid 1647); e Diego de Avendaño SJ (1594-1688) - Thesaurus Indicus (Anvers 1668-1686; t. I, tít. 9, cap. 12, §8)3.

Dito de modo muito breve e em linhas muito gerais, esses autores condenaram a escravidão ocorrente sem justo título (i.e.: de modo ilegal) e censuraram o tráfico de africanos que tivessem sido injustamente escravizados. Ademais, condenaram as condições subumanas e degradantes a que os africanos eram submetidos, bem como os múltiplos maus tratos e comportamentos inadequados cometidos pelos senhores de escravos. No entanto, nenhum desses autores fez uma verdadeira e radical defesa da liberdade dos escravos africanos. Ao contrário, muitos só pareceram ter se preocupado em tranquilizar a consciência dos senhores de escravos.

Todavia, esse modo de encarar o tema da escravidão negra só parece ter perdurado até o aparecimento, no último quartel do séc. XVII, de dois missionários que, conhecendo em primeira mão a crueza da realidade da escravidão e protestando contra essa realidade, redigiram dois tratados específicos sobre o tema consagrados a condenarem de modo peremptório a escravidão negra. Esses missionários são o frade aragonês Francisco José de Jaca OFMCap (1645-1689), autor da Resolución sobre la libertad de los negros y sus originarios, en estado de paganos y después ya cristianos ${ }^{4}$ e o frade borgonhês Epifanio de Moirans OFMCap (1644-1689), autor do tratado Servi liberi seu naturalis mancipiorum libertatis iusta defensio ${ }^{5}$.

\footnotetext{
${ }^{3}$ Fundamentalmente, sigo aqui García (Dos Defensores de los Esclavos Negros en el Siglo XVII. Maracaibo: Biblioteca Corpozulia; Caracas: Universidad Católica Andrés Bello, 1982, p. 2128). Esses autores também são referidos por Dutilleul (Esclavage. In: Dictionnaire de Théologie Catholique, t. 5, 1re partie. Paris: Letouzey et Ané, 1924, col. 506-516), que faz um instrutivo resgate histórico sobre o tema da escravidão entre os escolásticos e moralistas, por Cárdenas (La Ética Cristiana y la Esclavitud de los Negros. Theologica Xaveriana, n. 55, p. 227-257, 1980, p. 241-250), que defende que a Igreja não se omitiu ante o problema da escravidão negra e enfatiza a atuação dos jesuítas no tratamento desse problema, e por Mauricio (A Universidade de Évora e a Escravatura. Didaskalia, n.7, p. 53-200, 1977, p.164ss), que relata a posição da Universidade de Évora ante a escravidão e menciona outros jesuítas que se ocuparam do tema - como Fernão Pérez, Estêvão Fagundes e João Baptista Fragoso.

${ }^{4}$ Para informações sobre a vida, obra e pensamento de Jaca, cf., e.g.: GARCÍA, J. Dos Defensores de los Esclavos..., op. cit., p. 29-62; GONZÁLEZ, M. Francisco José de Jaca: una vida a favor de la liberación de los esclavos negros. Collectanea Franciscana, n.72, p. 599-671, 2002; Id. Estudio Preliminar. In: JACA, F. J. Resolución sobre la libertad de los negros, en estado de paganos y después ya cristianos. Madrid: CSIC, 2002, p. XXI-XCVIII; Id. Aportación antiesclavista en tierras de Indias, a fines del siglo XVII. In: MURILLO, I. (Ed.). El Pensamiento Hispánico en América: Siglos XVI-XX. Salamanca: Universidad Pontificia de Salamanca, 2007, p. 506-518; SARANYANA, J. (Dir.). Teología en América Latina. Volumen II/1. Madrid: Iberoamericana; Frankfurt: Vervuert, 2005, p. 303-307.

${ }^{5}$ Para informações sobre a vida, obra e pensamento de Moirans, cf., e.g.: GARCÍA, J. Dos Defensores de los Esclavos..., op. cit., p. 29-46.63-105; GONZÁLEZ, M. Aportación antiesclavista...,
} 
Esses religiosos amplificaram com intrepidez e paixão a realidade da escravidão que fora analisada friamente pelos autores que haviam se ocupado do tema e elaboraram um verdadeiro projeto antiescravista em pleno séc. XVII. Ademais, censuraram a escravidão tanto através de suas obras quanto de sua militância e atuação política. Com efeito, eles não eram doutores, mas missionários. Não se limitaram a serem teóricos, foram também práticos. Não escreveram apenas como juristas, mas bradaram com voz profética. Portanto, mais do que tratados sobre a escravidão, Jaca e Moirans escreveram verdadeiras denúncias das injustiças cometidas pelos cristãos contra o povo africano e não se intimidaram ante o que os autores anteriores haviam escrito, tampouco se acovardaram ante a mentalidade escravista da sociedade da época. Ao contrário, juntos, escreveram uma condenação substantiva e explícita da escravidão negra, do tráfico de escravos africanos e da sociedade escravocrata ibérica e iberoamericana.

E dada a importância desses autores, ainda pouco estudados, para a história das ideias sobre a escravidão, o propósito deste estudo é dar a conhecer alguns contornos do projeto antiescravista deles, mediante a apresentação das principais teses desse tão ousado e temerário projeto no que tange aos chamados títulos de justa escravidão ${ }^{6}$.

Como as ideias de Jaca e Moirans são bastante coincidentes e como Moirans tem um texto muito ordenado e sistemático e desenvolve com acuidade e precisão vários aspectos do referido projeto antiescravista - e inclusive teses que Jaca só havia esboçado sem, porém, desenvolvê-las -, este estudo abordará precipuamente a obra de Moirans, Servi Liberi ${ }^{7}$, mediante a reconstituição do núcleo argumentativo que constitui o ponto de partida de seu arrazoado condenatório da escravidão: o referente à análise dos títulos por meio dos quais um indivíduo podia legitimamente ser feito escravo. Esse núcleo é o lugar privilegiado para Moirans provar proposições sobre o tráfico que exigiam seu fim imediato, bem como a

op. cit., p. 519-530; Id. Epifanio de Moirans: misionero capuchino y antiesclavista. Collectanea Franciscana, n. 74, p. 111-145, 2004; Id. Doctrina antiesclavista de Epifanio de Moirans en su Servi Liberi. Naturaleza y Gracia, v. 52, n. 2, p. 279-327, 2005; Id. Estudio Preliminar. In: MOIRANS, E. Siervos Libres. Madrid: CSIC, 2007, p.XV-LXXIII.

${ }^{6} \mathrm{O}$ discurso sobre os títulos de escravidão corresponde a apenas uma parte do referido projeto antiescravista. A outra parte refere-se ao discurso sobre o tráfico, dado que o propósito dos autores não é só analisar se os africanos eram legitimamente escravizados, mas também elaborar um arrazoado capaz de exigir o fim do tráfico e de suas injustiças. Dada a envergadura do tema do tráfico, não o abordarei neste estudo.

7 Trabalho aqui com a edição crítica de Miguel Anxo Pena González (MOIRANS, E. Siervos Libres. Ed. M. González. Madrid: CSIC, 2007) e também com a tradução de José Tomás López García (MOIRANS, E. Siervos Libres. In: GARCÍA, J. Dos Defensores de los Esclavos..., op. cit., p. 179-298). No entanto, para fins de referência e citação, sigo sempre o texto estabelecido por González. 
manumissão dos escravos e a implementação de medidas corretivas para as injustiças cometidas pelos cristãos contra os africanos. Ademais, resume as linhas fundamentais do debate sobre a escravidão negra nos sécs. XVI-XVII e é central para compreendermos o projeto antiescravista dos missionários capuchinhos.

Antes, porém, de passar ao tratamento do discurso de Moirans sobre os títulos de escravidão, apresento uma breve nota informativa sobre sua obra. Escrita entre 1681 e 1682 e datada de 1682, quando Moirans está preso em Havana, a obra Servi Liberi é concebida tendo como base a Resolución de Jaca. Redigida em latim, contém 14 capítulos e 137 parágrafos, e trata-se de um tratado de filosofia, direito e teologia, com ênfase na moral. Quanto à estrutura, pode ser dividida em cinco partes: 1 . conclusões - estabelecidas na abertura da obra8; 2. prólogo e capítulo introdutório (Cap. I) - que explicam o que dá ocasião e motivo à obra e informam, mediante relatos de fatos presenciados pelo autor, toda a crueza da realidade da escravidão; 3 . análise dos títulos de justa escravidão (II-V); 4. disputa com autores adversários (VI-XI) - sobretudo com autores jesuítas (sendo Molina e Avendaño os alvos principais de Moirans); 5. discurso sobre a restituição (XII-XIV). Quanto ao argumento da obra, o mesmo é claro e fica visível a partir de sua estrutura: vencidas as considerações preliminares, Moirans analisa os títulos de escravidão a fim de provar que os africanos eram escravizados contra o direito e, no que segue, em um trabalho dialético hercúleo, refuta as posições de autores que, mesmo reconhecendo a existência de injustiça nas escravizações e no tráfico, mostraram-se tolerantes à manutenção do tráfico; finalmente, após todo o empenho refutatório realizado, Moirans conclui propondo a solução para o problema da escravidão negra: a restituição e a satisfação por todas as injustiças feitas contra os africanos injustamente escravizados. Por fim, no que se refere às fontes utilizadas pelo autor, detectam-se fontes próprias do âmbito teológico-moral (Sagrada Escritura, Magistério da Igreja, autores patrísticos, escolásticos e ibéricos que trataram de temas atinentes à guerra, à escravidão, ao comércio...), bem como do âmbito jurídico-canônico (Corpus Iuris Civilis e Corpus Iuris Canonici).

\footnotetext{
${ }^{8}$ Ao todo, Moirans estabelece cinco conclusões: “1. Ninguém pode comprar ou vender nenhum dos escravos de África, denominados comumente de negros; 2. Todos os que possuem alguns deles estão obrigados a manumiti-los, sob pena de condenação eterna; 3. Ao manumiti-los, os senhores devem pagá-los por seus serviços e indenizá-los; 4. Os negros habitantes de lugares das Índias nos quais são tidos por escravos, estão obrigados, por direito divino natural, a deixar esses lugares e a buscar outros lugares nos quais se cuide de sua salvação eterna; 5 . Por causa da injúria contra os negros, trasladados de suas terras e exportados às Índias, os príncipes cristãos fugirão dessas terras e perdê-las-ão, os bispos e clérigos emigrarão delas e navegarão como fugitivos e os cristãos serão feitos prisioneiros e escravos." Servi Liberi $(S L)$, Argumentum libri, p. 4.
} 


\section{Discurso sobre os titulos de justa escravidão}

Numa época em que a escravidão legal era uma instituição plenamente em vigor, praticamente não contestada pela Filosofia ou pela Igreja e, o que é mais importante, prevista pelo Direito Romano e Castelhano', era absolutamente normal que a questão sobre os títulos de escravidão merecesse atenção, posto que eram eles que legitimavam que a instituição vigorasse sem ser contestada.

Somando-se a isso, justificava-se a necessidade do tratamento dos títulos de escravidão por ser usual fazê-lo entre os autores. Desde Soto até Jaca, praticamente todos os que escreveram sobre a escravidão discorreram sobre ou ao menos citaram os títulos pelos quais alguém poderia tornar-se escravo e, nesse empenho, corroboraram a ocorrência e a legitimidade de quatro títulos básicos: por guerra justa - quando o prisioneiro de guerra era poupado pelo inimigo e feito escravo; por delito - quando a pena pela prática de um crime era a escravidão; por venda - quando a necessidade e a miséria obrigavam que alguém vendesse a si próprio ou a seu filho para sobreviver; e por nascimento - quando a criança nascia de uma mulher escrava.

No entanto, em vista de defender a liberdade dos escravos africanos, a atenção que Moirans dispensa aos títulos explica-se por duas razões: (a) para mostrar que o título de escravidão por guerra justa era impropriamente usado para justificar a escravização dos africanos e que, portanto, essa escravidão era ilícita; e (b) para mostrar que a base de fundamentação da escravidão não era tão ampla e sólida e que, logo, não havia tantos títulos para legitimá-la.

Por um lado, (a) é importante para Moirans condenar o caso da escravidão negra, já que era essa escravidão específica que lhe interessava impugnar, e não a escravidão simpliciter ou outras ocorrências de escravidão. Por outro, embora o próprio autor aceitasse a escravidão legal, (b) cumpre o papel de enfraquecer essa instituição, mediante a impugnação de títulos que gozavam de alguma aceitação, e, também, cumpre o mesmo papel de (a), ao suplementar a condenação da escravidão negra.

No que segue, exponho a posição de Moirans sobre o importante e sempre alegado título de escravidão por guerra e mostro como o autor leva a cabo o objetivo (a). Após, apresento sua posição sobre os títulos de escravidão por delito e por venda e explico em que medida o autor cumpre o objetivo (b).

${ }^{9}$ Cf., e.g.: Institutiones I, tít. 3-8; Digesta I, tít. 5-6; Partida IV, tít. 21-23. 


\subsection{Escravidão por guerra justa: um título legítimo, mas impropriamente alegado}

Quando Moirans escreve sua obra, o título de escravidão por guerra justa era amplamente aceito, sendo previsto tanto pelo Direito Romano quanto pelo Direito Castelhano ${ }^{10}$. Segundo esse título, aquele que era capturado em guerra justa podia ser feito escravo em vez de ser morto (exceto se a guerra ocorria entre povos cristãos). E Moirans admite a licitude da comutação da vida pela escravidão em caso de guerra justa, alinhando-se, assim, aos autores que o haviam precedido no tratamento da escravidão negra. Apesar disso, não reconhece de modo algum que esse título pudesse justificar essa escravidão, pois entendia que os africanos das regiões de onde os europeus (sobretudo os portugueses) retiravam escravos não eram escravizados em guerras que pudessem ser consideradas justas.

E Moirans propõe essa linha argumentativa seguindo de perto seu confrade Jaca - que também impugnara o título de escravidão por guerra denunciando a injustiça das guerras em que os africanos eram escravizados -, mas argumentando a partir da autoridade de S. Tomás de Aquino, como veremos - e não de Sto. Agostinho, como fizera Jaca ${ }^{11}$. Não obstante, o teor da justificativa do argumento de Moirans é substancialmente idêntico ao teor da explicação de Jaca: não há guerra justa entre europeus e africanos, tampouco entre os próprios africanos. Ademais, é substancialmente idêntico o caráter denunciatório do texto de Moirans, ao revelar a real causa das alegadas guerras - a cobiça - e a razão de tanta hostilidade contra os africanos - a crença de que eram um povo amaldiçoado e o fato de terem a cor da pele negra.

Em Servi Liberi, o argumento em vista de impugnar o título de escravidão por guerra justa insere-se na segunda parte do tratado, após as considerações do Prólogo e Cap. I. Apesar da importância dessas considerações, é na referida segunda parte que o tratado se adensa e se substancia, pois é nela que são provadas as três primeiras conclusões estabelecidas no início da obra. Especificamente, o argumento de impugnação do título da escravidão por guerra justa ocorre no Cap. IV, após Moirans ter provado que os africanos eram escravizados contra o direito natural (Cap. II) e contra o direito divino positivo (Cap. III). Com efeito, após ter analisado se os africanos poderiam ter sido legitimamente escravizados à luz dos direitos natural e divino positivo, Moirans finalmente analisa o principal campo do direito reivindicado para justificar a escravidão: o direito das gentes (ius gentium), já que a guerra e a escravidão legal eram típicas instituições desse ramo do direito ${ }^{12}$. E daí o título do Cap. IV ser "Os

\footnotetext{
${ }^{10}$ Cf., e.g.: Institutiones I, tít. 3, n. 3-4; Digesta I, tít. 5, n. 4.2-3; Partida IV, tít. 21, lei 1.

${ }^{11}$ Cf. Resolución I, n. 6.

${ }^{12}$ Cf., e.g.: Institutiones I, tít. 3, n. 2; Digesta I tít. 5, n. 4.1; Etymologiae V, n. 6; Decretum Gratiani I, dist. 1, cap. 9.
} 
negros são escravos contra o direito das gentes" (Contra ius gentium nigri sunt servi), dado que a intenção é justamente provar que sequer conforme esse direito podia ser legitimada a escravidão imposta aos africanos e o tráfico negreiro, apesar de ter se tornado usual entre os cristãos comprar e vender negros capturados na África, pois, segundo justifica o autor seu antagonismo ante o tráfico, citando o Direito Canônico, o costume não deve impedir que a verdade prevaleça e triunfe, tampouco deve prevalecer sobre o direito natural e divino positivo, pois o costume sem verdade significa a perpetuação do erro e, ademais, porque a corruptela é um erro que conduz os homens à danação eterna ${ }^{13}$.

No entanto, antes de provar que os africanos eram escravizados contra o direito das gentes, o próprio Moirans deixa evidente sua concordância com o título de escravidão por guerra, pois quer evitar opor-se a algo amplamente avalizado como legítimo - possivelmente (dentre outras razões) com o intuito de argumentar contra a escravidão partindo das mesmas premissas de que partiam os autores que se mostravam tolerantes à escravidão e ao tráfico - e, também, o que é mais importante, porque, enquanto filho de seu tempo e herdeiro de uma tradição de pensamento jurídico e teológico que majoritariamente considerou aceitável a comutação da liberdade pela vida e que detectou no erro moral (pecado) a porta de entrada para a escravidão no mundo, entendia que havia alguma racionalidade a fundamentar a instituição escravidão legal, visto que julgava ser conforme à razão (conforme rationi) que fosse feito escravo alguém que com justiça pudesse ser morto ${ }^{14}$. O motivo dessa concordância, porém, só é perfeitamente inteligível a partir do discurso de Moirans acerca da liberdade humana (apresentado no Cap. II, por ocasião da análise da legitimidade da escravidão negra à luz do direito natural), o qual, por sua vez, também esclarece o porquê de haver ausência de liberdade no mundo.

Segundo Moirans, todos os homens são livres por natureza e o bem da liberdade não pode ser retirado do homem. No princípio (por ocasião da criação de Adão), diz o missionário, citando a Bíblia (Eclo 15,14), Deus criou o homem e o deixou nas mãos de seu conselho (in manu consilii sui) ${ }^{15}$. Logo, desde o princípio o homem foi criado livre. E todos os descendentes desse primeiro homem feito livre também o são. Mas não só isso. Todos o são de modo que não podem ser apartados dessa liberdade, pois essa

\footnotetext{
${ }^{13}$ SL IV, 50, p. 70s. Cf. Decretum Gratiani I, dist. 8, cap. 8; Decretales Gregorii IX I, tít. 4, cap. 11. Esse mesmo argumento de que o costume e a corruptela não devem prevalecer sobre o direito reaparece no Cap. XI, que é dedicado à análise das justificativas de Avendaño para a manutenção do tráfico, quando Moirans refuta a segunda justificativa de que o tráfico tornou-se uma prática comum - cf.: SL XI, 114, p. 172s; Thesaurus Indicus I, tít. 9, cap. 12, §8, n 204. ${ }^{14}$ SL IV, 48, p. 68.

${ }^{15}$ Soto e Jaca fazem essa mesma citação na introdução ao tratamento do tema da escravidão, cf.: De iustitia et iure IV, q.2, a.2; Resolución I, n. 1.
} 
liberdade natural, situada na vontade de cada criatura racional, é tal que ninguém pode agir contra ela, nem mesmo Deus, pois a vontade onde a liberdade reside é dona de seus atos e, logo, não há nada capaz de violá-la ou tolhê-la ${ }^{16}$.

Nesse contexto, a existência de escravidão no mundo só se justifica em razão do mau uso da liberdade, i.e., por causa do pecado, o qual trouxe consigo não só a morte natural (mors naturalis), maior mal que alguém pode padecer, mas também a morte civil (mors civilis): escravidão civil/legal (servitus civilis/legalis), segundo maior mal que se pode sofrer ${ }^{17}$. A morte natural decorre do pecado de Adão e é transmitida (pertransivit) a seus descendentes. De outra parte, a morte civil decorre dos pecados pessoais e voluntários dos homens e só entra (intrat) nos pecadores que merecem a pena de morte (natural), a qual pode ser comutada pela escravidão (morte

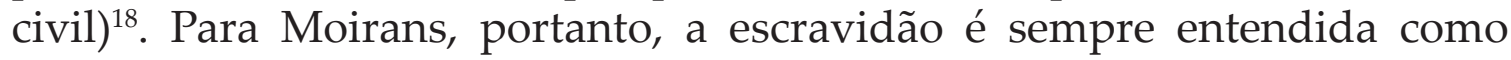
pena (poena) e só pode decorrer de um pecado cuja pena é a morte natural comutada pela morte civil, dado que a escravidão equipara-se à morte e, logo, havendo pecado, pode inclusive, com justiça e legitimidade, vir a seguir essa, pois se a morte é justa, então a escravidão também o é. E, de fato, é exatamente essa conclusão que esclarece o porquê da concordância do autor com o título de escravidão por guerra justa.

Ora, uma guerra justa nasce de um pecado ou delito do povo contra o qual é dirigida a guerra. E nessa guerra, dada sua justiça, é lícito punir e inclusive matar. Mas não só isso: é lícito e facultado punir os culpados fazendo-os escravos em vez de matá-los. E tudo isso é absolutamente aceitável e racional, pois, por mais degradante que seja a escravidão para um ser humano, mais vale perder a vida civil - e, logo, deixar de ser livre - do que ter de padecer o maior mal que há: a morte natural.

Todavia, isso tudo só é aceitável e racional se tais eventos (mortes e escravizações) ocorrem numa guerra justa e, portanto, se a campanha militar é movida por alguma injúria sofrida, pois, afinal, jamais seria justo tornar escravo um inocente ou mesmo condená-lo à morte senão em razão de um delito ${ }^{19}$.

\footnotetext{
${ }^{16}$ SL II, 25, p. 38.

${ }^{17}$ Essa hierarquia é estabelecida a partir do provérbio "A liberdade não se vende nem por todo o ouro do mundo" (Non bene pro toto libertas venditur auro), cuja origem é alguma versão latina da fábula "O cão e o lobo" de Esopo, e ocorre em Soto, que aponta que a liberdade vale mais que todo o ouro, mas não mais do que a vida, que é mais preciosa que todo o ouro (De iustitia et iure IV, q.2, a.2). Essa hierarquia permite que Moirans estabeleça uma equivalência entre "vida" e "liberdade" e outra entre "morte" e "escravidão", no Cap. II, e essas equivalências, por sua vez, serão importantes ao longo da obra, sobretudo quando o autor aborda o título de escravidão por venda rivalizando com Molina - cf., e.g., SL VI, 72 , p. $104-108$.

${ }^{18}$ SL II, 27-28, p. 38s.

${ }^{19}$ SL IV, 49, p. 68s.
} 
Apesar de concordar com o título de escravidão por guerra justa, em nada isso impediu Moirans de provar que os africanos eram escravizados contra o direito das gentes, posto que não pretendia provar a ilicitude do título em si, mas apenas a ilicitude das guerras em que os africanos eram escravizados e, logo, a ilicitude das escravizações praticadas.

Para tanto, valendo-se da conhecida teoria medieval da guerra justa e recorrendo à autoridade de seu grande sistematizador, Tomás de Aquino, Moirans analisa as guerras ocorrentes na África a partir das condições estabelecidas pelo Aquinate para uma guerra justa: (i) existência de autoridade legítima da república (príncipe/rei) para declarar a guerra; (ii) existência de causa justa (vingar uma injúria); e (iii) existência de reta intenção por parte do beligerante (ter em mira a paz e o bem da república ${ }^{20}$.

No parecer de Moirans, contudo, essas três condições inexistem tanto nas guerras entre os próprios africanos quanto nas guerras dos europeus contra os africanos ${ }^{21}$.

As guerras que ocorrem entre os africanos de Guiné e Cabo Verde não são guerras, mas sedições (seditiones), rapinas (rapinae) e latrocínios (latrocinia). $\mathrm{Na}$ verdade, os africanos dessas regiões não têm autoridades (reis/príncipes) ou república perfeita. Logo, travam entre si revoltas e guerras familiares, mas não guerras propriamente ditas, dada a carência de organização política em seu modo de vida. Ademais, o que na prática realmente faz que alguém se torne escravo não é algum título jurídico, mas simplesmente o fato de que os mais fortes, usando de violência, capturam os mais fracos para os venderem ou, caso não prevalecem em força, capturam quem quer que possam mediante dolo ou fraude. Destarte, está ausente aqui a primeira condição e, logo, inexiste possibilidade de alguma escravização ocorrer com justiça, sobretudo pelo fato de não haver nenhum direito a legitimá-la, mas tão só violência, dolo ou fraude ${ }^{22}$.

Em acréscimo, sequer a segunda condição está presente. Segundo aponta Moirans - emitindo, é verdade, um juízo depreciativo sobre os africanos, mas decerto com nobre intenção -, os africanos têm um modo de vida tão bárbaro que não examinam ou buscam causas por que lutar e sequer agem movidos por razões prudentes. Logo, lutam entre si movidos só por instinto, e não para vingar alguma injúria ou exigir reparação ou compensação. Não obstante, a verdadeira razão por que a segunda condição está ausente deve-se ao fato de os africanos travarem guerras entre si movidos por pura cobiça (cupiditas sola), visto que, sendo motivados pelo dinheiro dos traficantes, promovem guerras e fazem escravos com o único propósito de lucrar ${ }^{23}$.

${ }^{20}$ Summa Theologiae II-II, q.40, a.1. Cf. SL IV, 51, p. 72.

${ }^{21} S L$ IV, 52, p.7 2; 54, p. 76; 55, p. 76; 56, p. 78s.

${ }^{22}$ SL IV, 52, p.7 $2 \mathrm{~s}$.

${ }^{23}$ SL IV, 53, p. 74. 
E, por tudo isso, é evidente que também está ausente a terceira condição. Se, conforme denuncia Moirans, é a cupiditas sola a verdadeira causa das guerras ocorrentes entre os africanos, então é manifesto que inexiste reta intenção entre os beligerantes, pois o fim tido em vista é a própria cobiça (cupiditas ipsa), e não alguma preocupação com o bem da república ${ }^{24}$.

Não obstante, sequer as guerras entre europeus e africanos resistem à análise de sua justiça a partir das condições estabelecidas por Tomás de Aquino.

Quanto à primeira condição, Moirans aponta que não consta que os reis europeus (de Portugal, Espanha ou França) tenham declarado guerra aos africanos ou ordenado invasões a seus territórios em vista de pilhar e capturar negros, sobretudo porque não poderiam fazê-lo devido à ausência de causa justa. Assim, as invasões de europeus aos territórios africanos só podem ter razão de vingança privada ou latrocínio e rapina devido à cobiça, mas não razão de guerra justificada ${ }^{25}$.

E só em razão disso as alegadas guerras entre europeus e africanos já seriam injustas. Todavia, Moirans faz questão de também analisar essas guerras à luz das duas condições restantes, o que é notável, pois, ao fazê-lo, não só explicita a perversidade por trás da escravidão e do tráfico como também, em tom de denúncia, mostra que a responsabilidade e a culpa por todas as injustiças feitas contra o povo africano são dos próprios cristãos.

No parecer de Moirans, em primeiro lugar, inexiste causa justa de guerra contra os africanos pelo simples fato de não ter havido contato entre europeus e africanos que ensejasse que estes praticassem injúria contra aqueles. Destarte, quem realmente comete injúria são os europeus, não os africanos, os quais, por sua vez, por terem sofrido injúria, são os verdadeiros detentores dos direitos de guerra:

A segunda condição é absolutamente nula porque [os europeus] nunca viram a região dos negros na qual ingressam nem os negros viram os lusitanos ou outros europeus. Logo, como os europeus teriam recebido injúria deles? $\mathrm{Na}$ verdade, são eles próprios [os europeus] que causam injúria aos negros ao ocuparem suas terras e ao capturá-los e fazê-los escravos. Que grande injúria! E, por causa disso, não é porventura lícito aos negros matarem todos os lusitanos em compensação pelas injúrias que foram feitas até hoje e fazerem escravos todos os europeus em compensação por tantos milhões de negros deportados? Portanto, a causa justa está sempre do lado dos negros, não dos europeus ${ }^{26}$.

Além disso, inexiste causa justa de guerra porque sequer os cristãos buscam razões para invadir os territórios africanos e para escravizar os habitantes locais, uma vez que fazem isso movidos por uma espécie de ideologia

\footnotetext{
${ }^{24}$ SL IV, 54, p. 74s.

${ }^{25}$ SL IV, 55, p. 76.

${ }^{26}$ SL IV, 55, p. 76s.
} 
racista e escravista - cujo fundamento é o relato bíblico da maldição de Noé à Cam (Gn 9,20-29) -, que os impele a escravizar os africanos pelo simples fato de eles serem negros:

Os cristãos não examinam a causa com o juízo dos prudentes. Na verdade, quando podem, eles ingressam e capturam e roubam negros sem terem outra razão para isso senão o fato de que eles são negros e devem ser escravos, como se os negros não fossem verdadeiramente homens, mas animais ou cães e bestas, segundo dizem para justificarem as desculpas de seus pecados. E até o momento resta-lhes demonstrarem a causa justa da guerra, já que em nenhum momento ou lugar a demonstraram ${ }^{27}$.

Por certo, o que Moirans está a dizer aqui é que não só inexiste causa justa de guerra (por não ter havido contato entre europeus e africanos), como também que não há legitimidade ou cogência em justificar a escravidão negra a partir da propalada causa de escravidão baseada na crença de que os negros seriam da descendência de Cam (o filho amaldiçoado de Noé) e, logo, seriam um povo amaldiçoado e destinado a ser escravo, crença fomentada sobretudo por Sandoval ${ }^{28}$.

E que a intenção de Moirans seja responder a quem arrolava a teoria dos filhos de Cam como fundamento da escravização dos africanos, em vista de desacreditar a hipótese de alguma fundamentação bíblico-teológica para a escravidão negra, é algo evidente na obra, uma vez que, ao examinar se os negros eram legitimamente escravizados à luz do direito divino positivo no Cap. III, Moirans refere que há cristãos loucos cheios de cobiça que creem estar isentos de terem de apresentar os títulos de escravidão em razão de os negros terem sido amaldiçoados pelo próprio Deus ${ }^{29}$.

${ }^{27}$ SL IV, 55, p. 78.

${ }^{28}$ Em Sandoval, a adesão a essa crença pode ser notada quando o autor tenta explicar por que os negros tinham a cor da pele negra. Após eliminar a hipótese de que a negrura pudesse decorrer da imaginação dos pais na hora da concepção ou da exposição a um clima demasiado quente e ensolarado, Sandoval passa a trabalhar com uma dupla hipótese: a negrura provém de uma qualidade particular possuída intrinsecamente no corpo - o sumo calor; bem como do fato de Deus ter feito essa qualidade particular inata em Cam (do qual descendem os negros), para que os filhos que engendrasse tivessem a tez negra, como marca de que descendiam de um homem amaldiçoado. Cf. De instauranda... I, cap. 2 (1aㅡ ed). Cf. também: SOUZA, J. Las Casas..., op. cit., p. 39; PICH, R. Alonso de Sandoval and the Ideology of Black Slavery. Patristica et Mediaevalia, n.36, p. 51-74, 2015, p. 55-60). Na versão de 1647 de De instauranda..., Sandoval dá muito mais detalhes ao explicar a causa da negrura, chegando a dedicar dois capítulos só para isso (cap. 2-3), posto que amplia o conteúdo do cap. 2 da versão de 1627. Apesar disso, não se podem verificar mudanças substanciais quanto ao texto de 1627, pois, apesar de se preocupar em fazer distinções entre Cam e Canaã e entre os filhos daquele (algo que não havia feito na $1^{\underline{a}}$ ed.), continua relacionando a negrura ao pecado de Cam, à maldição de Noé, bem como à escravidão, vergonha, mácula e feiura - cf. De instauranda... I, cap. 3, n. 4-10 (2 ${ }^{\underline{a}}$ ed). Cf. também Juan de Solórzano y Pereira, De Indiarum Iure I, cap. 10, n. 47-52, autor importante no contexto do pensamento da época e que também explica a negrura valendo-se do relato da maldição de Noé, sendo inclusive citado por Sandoval.

${ }^{29}$ SL III, 40, p. 56: "Loucos e cheios de cobiça, [os cristãos] respondem que os negros são animais que vivem como bestas, amaldiçoados por Deus, da progênie de Cam, a quem Noé amaldiçoou e fez servo dos filhos de Sem. E, então, dizem que não é preciso justificar 
Para Moirans, todavia, não há qualquer legitimidade em dizer isso porque, tratando-se do direito das gentes, não faz sentido recorrer a pressupostos bíblico-teológicos, tampouco ao fator cor da pele como eventual título de escravidão, pois tais elementos são absolutamente estranhos ao que é legalmente previsto. Em seu parecer, se a causa da guerra não for alguma injúria sofrida, então não há fundamentação bíblico-teológica ou ideologia racista capaz de justificar o infligimento da segunda pena mais dura que alguém pode sofrer na vida (morte civil), pois essa pena só é merecida a quem é realmente culpado por algo, e não a quem é supostamente culpado (em razão do pecado de um ancestral) ou a quem é diferente por sua cor de pele.

Ademais, Moirans pensa que é impróprio alegar a teoria dos filhos Cam como fundamento para a escravização dos africanos em razão da falta de cogência que há nisso. É verdade que Moirans concede que a escravidão que há no mundo decorre do pecado (como vimos). No entanto, nada o convence de que a escravidão que o povo africano padece decorra do pecado de algum ancestral amaldiçoado pelo próprio Deus.

Ao contrário de Sandoval, que interpretou a maldição de Noé contra o filho de Cam (Canaã) extensivamente a toda a descendência de Cam (Cus, Mesraim, Fut e Canaã) e que viu na cor da pele dos negros um sinal de maldição e servidão ${ }^{30}$, Moirans aponta que a maldição contra o filho de Cam aplica-se exclusivamente a Canaã (repetindo exatamente o que consta no texto bíblico), bem como que não é possível estabelecer alguma conexão entre os povos dos cananeus da Palestina (Ásia) e os povos dos negros da África, parte ocidental ${ }^{31}$. E, por conseguinte, obviamente, Moirans sequer propõe alguma teoria de que a cor de pele negra constitua uma marca de maldição ou servidão, porque não vê guarida bíblica para isso e porque não parece estar convencido de que os negros carregariam alguma culpa hereditária em razão do pecado de Cam, tampouco de que a pena por tal culpa seria a morte civil. Os negros, igualmente aos demais homens, carregam uma culpa hereditária devido ao pecado original e essa culpa tem como pena a morte natural, que passa de homem para homem (negro ou não) desde Adão. No entanto, a morte civil é algo que decorre essencialmente dos pecados pessoais e voluntários que merecem a morte, ou ainda: é algo que decorre de um pecado cometido, não contraído ou herdado, e

os títulos de escravidão e que não é contra o direito natural divino ou positivo ter negros como escravos, mas que, segundo a justa sentença que procede de Deus, se pode capturá-los, fazê-los escravos e tê-los como escravos, porque por Deus os negros foram declarados escravos dos outros com essas palavras de Noé: 'Maldito Canaã, será servo dos servos para seus irmãos. Bendito o Senhor Deus de Sem, seja Canaã seu servo' (Gn 9,25s). Ademais, os cristãos sucederam os filhos de Sem em seu lugar e então se diz: 'Que Deus dilate Jafé e habite nos tabernáculos de Sem e que Canaã seja seu servo' (Gn 9,27). Logo, os negros, que descendem de Cam, foram declarados e feitos escravos dos cristãos por Deus. E não há por que justificar outro título de escravidão além deste."

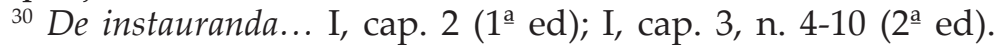

${ }^{31}$ SL III, 41, p. 58s. 
trata-se, pois, de uma consequência de um ato, não de um estado. Para Moirans, portanto, a morte civil não é algo que seria transmitido, tampouco algo que mereceria uma marca própria como a pele negra; e daí ele dizer que os cristãos agem como "loucos cheios de cobiça", já que se apegam a uma teoria pouco cogente em vista de justificarem seus pecados e suas injustiças contra os negros.

Por fim, considerando-se tudo o que foi dito sobre a possível ocorrência de causa justa, é notório que inexiste possibilidade de haver reta intenção por parte dos que fazem guerras contra os negros. Segundo o capuchinho, a única retidão que os cristãos têm é a da cobiça (rectitudo cupiditatis). Destarte, não existe nem pode haver reta intenção em suas ações, já que eles promovem crimes, movem guerras e fazem escravos movidos pela cobiça e pela avidez por lucros. E quaisquer retas intenções alegadas só podem ser tomadas a título de pretexto (praetextum), pois, na verdade, eles não têm nenhuma intenção reta ou boa para com os africanos ${ }^{32}$.

E que a cobiça seja a verdadeira (e secreta) intenção dos cristãos é algo evidente para Moirans, uma vez que os cristãos, embora aleguem intenções pias e nobres, são traídos por seu comportamento. Arrolando a si próprio como testemunha do que diz, a partir de sua experiência missionária em regiões de colônias francesa e espanhola, Moirans aponta que os cristãos não assistem aos negros no tocante ao espiritual e ao temporal, tampouco se preocupam com a salvação deles. Logo, não faz sentido alegarem que escravizam e traficam negros em nome da fé e para fazê-los cristãos ${ }^{33}$.

E, ao dizê-lo, Moirans faz um movimento argumentativo interessante, que revela seu afastamento em relação a um posicionamento teórico ante a escravidão negra que poderíamos chamar de utilitarista, por relevar a ocorrência da escravidão e do tráfico em nome de um bem maior para a cristandade - a propagação da fé e a conversão de pagãos - e, é claro, em nome de um presumido bem maior para os próprios africanos, os quais teriam melhor sorte vivendo entre cristãos do que em suas nações originárias como pagãos, pois, servindo a um senhor de escravos cristão, eles teriam a possibilidade de se instruírem na doutrina cristã, receberem os sacramentos e até mesmo alcançarem a salvação $0^{34}$.

Moirans, contudo, mostra-se incrédulo ante a reta intenção de cristianizar os africanos escravizando-os. É claro que ele não discorda de que é melhor ser cristão do que não sê-lo. Em si, a tese de converter os africanos não lhe é problemática. Todavia, Moirans tem uma grande incredulidade, a

\footnotetext{
${ }^{32}$ SL IV, 55-56, p. 78.

${ }^{33}$ SL IV, 56, p. 78.

${ }^{34}$ Vitoria e Molina pareceram ter endossado de alguma forma essa posição - cf., e.g. a carta de Vitoria a Bernardino de Vique (In: VITORIA, F. Political Writings, op. cit., p. 335), bem como De iustitia et iure I, trat. 2, disp. 35, n. 19. Cf. também a carta de Luis Brandão a Sandoval, em De instauranda... I, cap. 17 (1ํㅡㄹ ed); I, cap. 22, n. 3 ( $2^{\underline{a}}$ ed).
} 
incredulidade de quem sabe como as coisas funcionam na prática e não vê as coisas acontecerem. Com efeito, Moirans não fala como doutor, mas como missionário, vivendo entre índios e escravos africanos nas colônias, que não verifica a concretização das boas intenções cristãs e que, portanto, só encontra mesmo desculpas.

Não obstante, Moirans não faz objeção só por desconfiar das boas intenções dos cristãos, mas também por se opor ao método de propagar a fé cristã por meio da escravidão. Ora, se os cristãos realmente tivessem a intenção de converter os africanos, que necessidade haveria de escravizá-los, traficá-los e deportá-los? Se a intenção fosse converter, então o natural seria que os cristãos fossem até a África e pregassem a doutrina cristã aos negros em suas próprias regiões ${ }^{35}$. E a razão de Moirans para dizê-lo parece ser a mesma alegada por Soto, que, um século antes, já havia criticado tal método de evangelizar os africanos ao dizer que a fé deve ser ensinada com suma liberdade ${ }^{36}$.

De outra parte, Moirans pensa que é equivocado alegar a intenção de converter os negros escravizando-os e traficando-os porque isso equivale a fazer um mal em vista de extrair um bem. Para o capuchinho, entretanto, não faz sentido propagar a fé através de injúrias, injustiças, dolos e fraudes. Logo, não pode ser reta a intenção de quem promove a guerra alegando a propagação da fé. Na verdade, para os cristãos, difundir essa fé não é uma intenção, é apenas um pretexto, cujo propósito é mascarar suas intenções (essas, sim, verdadeiras) de obterem lucro ${ }^{37}$.

Com essa análise das condições para uma guerra justa, Moirans esperou ter conseguido mostrar que o importante título de escravidão por guerra era impropriamente alegado e que, portanto, a escravidão imposta aos africanos era ilícita. No entanto, ele tinha ciência de que também os títulos de escravidão por delito e por venda eram alegados. E por isso fez questão de analisá-los, ainda que de modo breve. Seu objetivo ao analisá-los, porém, não é o mesmo que teve em vista ao abordar o tema da guerra, pois, antes de tudo, parece que o que lhe estava em questão era mostrar que a base de fundamentação da escravidão (ou ao menos a base de justificação da escravidão negra em específico) não era tão ampla como se alegava.

\subsection{Escravidão por delito e por venda: alegação imprópria e legitimidade questionável}

A análise ex professo dos títulos de escravidão por delito e por venda dos filhos ou de si próprio ocorre no Cap. V de Servi Liberi. Contudo, essa

\footnotetext{
${ }^{35}$ SL IV, 56, p. 78.

${ }^{36}$ De iustitia et iure IV, q.2, a.2.

${ }^{37}$ SL IV, 56, p. 78.
} 
análise não se circunscreve a esse capítulo, pois, como esses títulos têm sua origem no direito natural, o leitor é remetido ao Cap. II. Ademais, no caso do título de escravidão por venda, a análise estende-se para o Cap. VI, que dá início a terceira parte do tratado, na qual Moirans disputa com autores adversários, e principalmente com Molina, que havia dado significativa atenção ao título da venda ${ }^{38}$ e que é confrontado duramente por Moirans no Cap. VI.

Para mostrar que a base de fundamentação da escravidão (ou ao menos a base de justificação da escravidão negra em específico) não era tão ampla e que, portanto, não havia tantos títulos para legitimá-la, Moirans, em primeiro lugar, por ocasião da análise do título de escravidão por delito, argumenta adotando uma estratégia similar à utilizada para provar que não podia haver guerras justas entre os africanos e, em segundo lugar, por ocasião da análise do título de escravidão por venda, argumenta defendendo a tese de que a escravidão só pode justificar-se como um caso de servare - i.e.: para conservar (servare) a vida -, bem como denunciando ilegalidades na aplicação do título e inclusive algumas inconsistências no que diz respeito à legitimidade em si do título.

Para provar que o título de escravidão por delito era impropriamente alegado, Moirans retoma uma tese do Cap. II, onde discursara sobre a liberdade natural do homem e explicara que essa é perdida em razão do pecado. No entanto, segundo aponta, embora somente o cometimento de um delito ou pecado enseje a perda dessa liberdade, é requerida uma dupla condição para alguém ser legitimamente escravizado: (1) ter cometido um delito; (2) ter sido punido pelo delito (i.e.: ter sido feito escravo) por uma autoridade pública ${ }^{39}$.

E com essa tese em mente, prescindindo absolutamente de averiguar se os africanos cometiam delitos, Moirans invalida o título de escravidão asserindo simplesmente que os africanos não viviam politicamente nem tinham direito civil, reis ou juízes ${ }^{40}$.

É verdade que Moirans substancia sua prova emitindo também outros juízos empíricos sobre os africanos - viz.: "eles se escravizam tomando a outros por violência ou dolo e fraude" (logo: não em razão de delito devidamente punido por autoridade pública) e "são escravizadas inclusive crianças, que são inocentes" (logo: não devido ao cometimento de um delito) ${ }^{41}-$, contudo, o ponto fundamental de seu argumento segue a mesma linha adotada para invalidar o título de escravidão por guerra.

${ }^{38}$ Cf., e.g., De iustitia et iure I, trat.2, disp.33, n.14-31; disp.35, n.9-12.

39 SL II, 30, p. 42.

40 SL V, 58, p. 82.

41 SL V, 58, p. 82. 
E embora possa ser surpreendente o juízo depreciativo que Moirans emite sobre o modo de vida dos africanos, pode-se dizer que o autor faz isso justamente para defender a liberdade deles. É claro que Moirans, assim como outros autores, pensava que os africanos das regiões de Cabo Verde e Guiné eram política e culturamente atrasados. No entanto, é interessante notar que em vez de ver nisso uma razão que eventualmente pudesse favorecer o fomento da dominação sobre os negros a título de ato civilizatório, Moirans vê no modo bárbaro de vida dos africanos uma razão capaz de justificar sua libertação.

Não obstante, a abordagem mais interessante desses títulos remanescentes concerne ao da escravidão por venda. Ao tratar desse título, Moirans parece ir além da simples condenação da legalidade de sua prática, pois manifesta certa desaprovação e discordância quanto à legitimidade em si do título, algo que não havia ocorrido quando analisou os dois primeiros títulos.

Antes de expor a análise que Moirans faz desse título, é importante esclarecer que há duas modalidades dele ${ }^{42}$ :

(i) venda do filho pelo pai, posto que o filho é algo do pai, em situação de necessidade, a fim de garantir a sobrevivência do pai;

(ii) venda de si próprio, posto que cada pessoa é senhora de seus bens, de sua honra, reputação e liberdade, em situação de necessidade, a fim de garantir a própria sobrevivência.

Essas duas modalidades são censuradas por Moirans. Contudo, por razões e de modos diferentes, posto que Moirans concorda com (i), ao menos em parte, e discorda de (ii). E isso, por um lado, no caso de (i), o leva a criticar sobretudo a legalidade do modo como ocorriam as vendas - a partir de uma análise de caso e de juízos empíricos (algo que já é bem familiar a quem viu o modo como refutou os títulos precedentes) - e, por outro, no caso de (ii), o leva a criticar a própria possibilidade de haver alguma legitimidade nas vendas (quaisquer que fossem) - a partir da detecção de uma contradição no título da venda.

No caso da modalidade (i), com a qual concorda por entender que efetivamente o filho é algo do pai (filius sit aliquid patris), Moirans aponta que as vendas ocorrentes estavam longe de satisfazerem a condição que é a razão de ser do título: o suprimento de uma necessidade. Ora, se o título existia em vista da consecução de um bom propósito (como o suprimento de uma necessidade), então a imposição a um filho de algo tão degradante como a escravidão devia minimamente proporcionar aquele bom

\footnotetext{
${ }^{42}$ Essas duas modalidades são bem diferenciadas, e.g., nos tratados De iustitia et iure de Soto (IV, q.2, a.2) e Molina (I, trat. 2, disp. 33, n. 14-31). Moirans não as distingue explicitamente como esses autores, mas faz questão de tratar de ambas e de condenar ambas.
} 
propósito. Mas, segundo comprova a experiência, não era isso que ocorria quando os pais africanos vendiam seus filhos, pois eles os entregavam por valores ínfimos ou aceitam como pagamento coisas que não os ajudavam a sobreviver. Logo, a venda não remediava a necessidade ${ }^{43}$. E isso seria motivo suficiente para a ilegalidade das vendas, pois Moirans enumera essa razão ao lado de outra razão, também comprovada pela experiência, que inequivocamente anulava a legalidade das vendas e do título: o fato de que as vendas ocorriam indiscriminadamente e de que não raramente era o filho quem vendia o pai $^{44}$.

Ademais, especula Moirans, se o problema era suprir uma necessidade e se o pai podia forçar o filho a algo, então faria mais sentido - pois seria mais eficiente - que os pais obrigassem seus filhos a trabalharem em vez de vendê-los ${ }^{45}$. E, ao dizê-lo, Moirans realça que sua concordância com o título é apenas parcial, pois, na verdade, embora não o considere impossível, ele o tem na conta de pouco provável, já que, em razão do pátrio poder, e em havendo realmente necessidade, os pais poderiam dispor de alternativas mais eficazes para remediarem sua situação.

E nessa mesma linha de deslegitimação do título, mediante a detecção de eventuais pontos questionáveis e, logo, vulneráveis, Moirans o condena por ser ofensivo à conduta cristã.

Moirans estava ciente de que Molina o havia defendido, contanto que fosse pago um preço justo pela liberdade daquele que era entregue como escravo, contudo, discorda do autor jesuíta no que diz respeito ao caráter cristão do ato de comprar um filho de um necessitado ${ }^{46}$. Segundo o capuchinho, os cristãos não poderiam comprar os filhos dos africanos porque, na verdade, estando esses em situação de miséria e necessidade, os cristãos estariam, antes de tudo, obrigados a socorrê-los de modo gratuito e caritativo - ao invés de negociarem com eles ${ }^{47}$. No parecer de Moirans, ainda que pudesse haver alguma justiça no título (como veremos), era inegável que lhe faltava absolutamente a caridade, pois, segundo é sugerido, sendo-se cristão, negociar com pessoas indigentes seria de uma desumanidade e mesquinhez incompatíveis com a mensagem evangélica. E daí o autor dizer que Molina se apartou do Evangelho e da caridade, ao admitir como justo um ato tão pouco cristão ${ }^{48}$.

Em acréscimo, Moirans condena o título da venda por também ser contrário à justiça, e não só à caridade. E ao fazê-lo, desta vez já no Cap. VI, Moirans não se preocupa em distinguir as modalidades (i) e (ii) e critica ambas.

\footnotetext{
${ }^{43}$ ID V, 59, p. 84.

${ }^{44}$ ID V, 59, p. 84.

${ }^{45}$ ID V, 59, p. 84.

46 SL VI, 71-72, p. 104-108.

47 SL V, 59, p. 84.

48 SL VI, 72, p. 104.
} 
A ofensa à justiça decorre de a permuta realizada nas compras não ser equitativa, ao menos tal como o título era concebido por Molina. Com efeito, embora considerasse o título avesso à caridade, Moirans acreditava que havia alguma justiça nele, contudo, jamais do modo como o mesmo era alegado por Molina, que propunha que a situação justificável para alguém vender a si próprio ou a um filho fosse de grave necessidade (gravis necessitas) $^{49}$.

Segundo Moirans, é falso e contra o direito que o pai em grave necessidade pode vender o filho ou a si mesmo, pois a escravidão é a morte civil. Logo, só em caso de extrema necessidade (extrema necessitas) é lícita a venda: para evitar a morte natural. Como a escravidão se equipara à morte e é mais grave que a miséria, não é lícito vender a si mesmo ou a um filho em razão de uma grave necessidade, mas apenas por extrema necessidade ${ }^{50}$.

Conforme vimos, no discurso de Moirans sobre a liberdade, a existência de escravidão no mundo deve-se ao pecado, que trouxe consigo não só a morte natural como também a morte civil: escravidão legal, que decorre dos pecados pessoais e voluntários dos homens e que entra naqueles que merecem a pena de morte (natural), a qual pode ser comutada pela escravidão (morte civil). E tudo isso levou Moirans a concluir que a escravidão é essencialmente pena e só pode decorrer de um pecado cuja pena é a morte natural comutada pela morte civil.

Não obstante, mesmo que a escravidão só se justifique por causa do pecado, Moirans, ao abordar o título da venda, flexibiliza a exigência de pecado anterior e admite que a escravidão se justifique apenas como comutação. É interessante notar, contudo, que essa flexibilização não amplia a base de justificação da escravidão. Ao contrário, limita-a, pois a exigência de grave necessidade é substituída pela exigência de uma extrema necessidade, entendida como alto risco de perder a vida natural.

Basicamente, por trás do argumento de Moirans está a ideia de limitar a escravidão a um caso de servare, i.e., a um ato de conservação da vida, inclusive quando inexiste pecado pessoal prévio que a justifique. Para Moirans, apesar de o pai ter poder sobre o filho (e, logo, poder dispor dele) e de cada homem ter poder sobre si próprio (e, logo, poder dispor de sua liberdade), se a escravidão não decorrer de um pecado, então ela só pode justificar-se para conservar o maior bem do homem: a vida natural. A escravidão é uma instituição degradante e odiosa. Logo, dizer que alguém entrega um filho para ser escravo de bom-grado ou abraça a escravidão voluntariamente só pode ter sentido se a situação for realmente de extrema necessidade.

\footnotetext{
${ }^{49}$ Cf. De iustitia et iure I, trat. 2, disp. 33, n. 21ss; disp.3 5, n. 9ss.

${ }^{50}$ SL VI, 72, p. 106.
} 
Moirans estava ciente de que o título da venda era impropriamente alegado e que era considerado aceitável contanto que a liberdade fosse comprada por um preço justo. Por isso, o critica não só em relação à sua prática dizendo, e.g., que a venda não suprimia a necessidade -, mas também em relação à sua legitimidade, pois discordava de que alguma legitimidade pudesse ser garantida apenas mediante uma negociação justa. $\mathrm{O}$ aspecto contratual da alienação da liberdade é uma das condições a ser considerada para legitimar o título, não é a única nem a mais fundamental. Antes e acima do aspecto contratual, a legitimidade do título depende da equidade da permuta no que concerne ao indivíduo que aliena ou tem alienada sua liberdade. Ou seja, tal legitimidade depende de que a liberdade que é vendida seja, no que diz respeito ao indivíduo que a aliena (em sua pessoa ou na do filho), trocada por algo equiparável a ela.

Como se equipara à morte, a escravidão é mais grave que a miséria. Logo, só pode ser comutada pela morte, não pela miséria. E não há preço justo que pague a liberdade comutada por algo inferior à vida ${ }^{51}$. Nem mesmo se o preço for todo o ouro do mundo, pois a liberdade não é um bem mensurável por um preço. E daí que Moirans seja tão irônico ao ponto de perguntar se porventura Molina venderia a si próprio ou acharia certo que seu próprio pai o vendesse em caso de grave necessidade ${ }^{52}$, pois, sendo obviamente Molina sabedor do valor inestimável da liberdade, jamais ele próprio concordaria em vender ou ter vendida sua liberdade, porque, exceto a morte, não há miséria mais grave que a escravidão.

E o tratamento do título da venda é concluído com uma análise isolada da modalidade (ii). Mais especificamente, com uma breve análise sobre o resultado da negociação para quem vende sua liberdade, resultado o qual, se considerado com atenção, é sempre inútil e revelador do quão falaz é o título. Conforme Moirans, o homem que vende a si mesmo recebe em vão o preço de sua liberdade, pois, na verdade, nada recebe por ela. Quando se torna escravo, nada mais é seu, mas de seu senhor. Logo, não se vende por si, mas por outro; e o preço recebido não é seu, mas de outro. Mas não é lícito vender-se por outro, pois quem se vende não ajuda a si, mas a outro. Logo, perde sentido o título, pois quem vende a si mesmo torna-se uma pessoa miserável sob o domínio de outro ${ }^{53}$.

E perdendo o sentido a modalidade (ii) e sendo os demais títulos ilegais quanto à sua aplicação, a conclusão subjacente é: que a base de fundamentação da escravidão legal não era tão ampla - pois havia títulos impropriamente alegados ou questionáveis; e que a base legal da escravidão negra era mínima, para não dizer inexistente, posto que africanos eram escravizados em massa contra o direito, seja porque algumas condições

${ }^{51}$ SL VI, 71, p. 104s.

52 SL VI, 72, p. 106.

${ }^{53}$ SL VI, 72, p. 106. 
não eram satisfeitas para a legalidade da escravização, seja porque a grande maioria dos africanos era escravizada sem que houvesse alguém minimamente preocupado com a justiça do ato de escravização ou com o direito natural deles à liberdade.

\section{Conclusão}

À guisa de conclusão, ainda que parcial, posto que só abordei neste estudo um aspecto do projeto antiescravista Moirans - e, por extensão, também de Jaca -, deixando de lado a argumentação referente ao tráfico, é oportuno notar que, por si mesmo, o discurso de Moirans sobre os títulos de escravidão desempenha um papel singular e significativo na história das ideias sobre a escravidão negra no contexto da Escolástica Barroca. E a razão disso é que se trata de um discurso cuja ênfase está toda ela canalizada em vista de denunciar ao leitor as múltiplas injustiças por trás da escravidão negra e (em vista de) proclamar insistentemente que os africanos traficados e deportados eram livres, ou melhor, eram "servos livres" (servi liberi), pois não haviam sido legitimamente escravizados, e, logo, eram livres, conquanto estivessem na condição de servos. Em suma, a singularidade e a importância do discurso de Moirans reside no fato de que se trata de um discurso engajado e não neutro, o que é notável, por ser algo incomum frente à sociedade e ao contexto intelectual em que se insere.

É claro que Moirans, tal como os autores que o precederam, não se esquiva de adentrar nos meandros legais inerentes ao tema da escravidão, tampouco evita proceder análises essencialmente jurídicas. Moirans não é um militante insano que abraçou a defesa de uma causa sem um autêntico convencimento racional ou movido por pura simpatia pelos africanos! No entanto, ao contrário de autores que se apegaram ao legalismo do tema falando invariavelmente da escravidão em tese, e evitando dizer algo a partir de juízos empíricos, e que, assim, acabaram revelando-se tolerantes à manutenção da escravidão negra e à continuidade do tráfico, Moirans apresenta um discurso sobre os títulos de escravidão que está radicalmente comprometido com a defesa da liberdade dos escravos africanos e que não é afeito a análises acadêmicas demasiado teóricas ou a algum tipo de neutralidade.

Esse discurso levou Moirans a concluir que os escravos africanos não eram justamente escravizados em conformidade com o título de escravidão por guerra justa, tampouco em conformidade com os títulos de escravidão por delito e por venda. E essa conclusão foi-lhe fundamental não só para afirmar que os escravos africanos eram livres e para elaborar seu discurso sobre o tráfico, mas também para provar as três primeiras conclusões que abrem o tratado Servi Liberi, as quais, por seu turno, levaram-no a estabelecer a principal conclusão de todo tratado, a qual, embora subja- 
cente, é retumbante para o leitor: o tráfico deve parar imediatamente, os cristãos devem pagar por seus malfeitos e medidas restaurativas devem ser implementadas para se corrigirem as múltiplas injustiças cometidas contra o povo africano.

Por fim, apesar dessa bela conclusão, a fim de bem entendermos o autor e suas proposições, não podemos deixar de notar que Moirans foi filho de seu tempo e está longe de poder ser considerado um abolicionista. É verdade que ele considerava a escravidão legal uma instituição degradante e odiosa, bem como um dos grandes males que aterrorizava o mundo e só não um mal pior do que a morte física. Contudo também é verdade que ele sempre considerou tal instituição como legítima.

É evidente que a causa por que Moirans lutou era nobre, mas essa causa ainda não era o abolicionismo. Na verdade, Moirans jamais pregou o fim da instituição escravidão, mas o fim das injustiças cometidas pelos cristãos contra os africanos. Portanto, jamais condenou a escravidão como tal, mas apenas a escravidão negra e o tráfico de escravos africanos. De qualquer forma, parece indiscutível a importância de Moirans para a história das ideias sobre a escravidão, pois seu projeto antiescravista o torna um grande defensor da liberdade dos escravos africanos. E seu discurso sobre os títulos de escravidão parece revelar isso claramente, pois se trata de um discurso de afirmação da liberdade daqueles que tiveram usurpada sua liberdade.

\section{Bibliografia}

ALBORNOZ, B. Arte de los contractos. Valencia: Pedro de Huete, 1573.

ALFONSO X. Las Siete Partidas. Madrid: Imprenta Real, 1807. 3t.

ALONZO, M. From Slave Driver to Abolitionist: Bartolomé de Las Casas on African Slavery. Patristica et Mediaevalia, n. 36, p. 17-28, 2015.

ANDRÉS-GALLEGO, J. La esclavitud en la América española. Madrid: Encuentro, 2005. . La Iglesia y la Esclavitud de los Negros. Pamplona: EUNSA, 2002.

AÑOVEROS, J. Luis de Molina y la Esclavitud de los Negros Africanos en el siglo XVI. Revista de Indias, v. 60, n. 219, p. 307-329, 2000.

AQUINO, T. Suma Teológica. São Paulo: Loyola, 2004. v. 5.

AVENDAÑO, D. Thesaurus Indicus. Antuerpiae: Iacobum Meursium, 1668. t.1.

Biblia Sacra juxta Vulgatam Clementinam. Editio Electronica. Londini, 2005.

BOXER, C. A Igreja Militante e a Expansão Ibérica: 1440-1770. São Paulo: Companhia das Letras, 2007.

CÁRDENAS, E. La Ética Cristiana y la Esclavitud de los Negros. Theologica Xaveriana, n. 55, p. 227-257, 1980. 
Corpus Iuris Canonici. Ed. Friedberg. Lipsiae: Bernhardi Tachnitz, 1879-1881. 2 v.

DAVIS, D. The Problem of Slavery in Western Culture. Oxford: OUP, 1966.

DUTILlEUL, J. Esclavage. In: Dictionnaire de Théologie Catholique, t. 5, 1re partie. Paris: Letouzey et Ané, 1924. col. 457-520.

GARCÍA, J. Dos Defensores de los Esclavos Negros en el Siglo XVII. Maracaibo: Biblioteca Corpozulia; Caracas: Universidad Católica Andrés Bello, 1982.

GONZÁLEZ, M. Aportación antiesclavista en tierras de Indias, a fines del siglo XVII. In: MURILlO, I. (Ed.). El Pensamiento Hispánico en América: Siglos XVI-XX. Salamanca: Universidad Pontificia de Salamanca, 2007. p. 489-530.

. Doctrina antiesclavista de Epifanio de Moirans en su Servi Liberi. Naturaleza y Gracia, v. 52, n. 2, p. 279-327, 2005.

- Epifanio de Moirans: misionero capuchino y antiesclavista. Collectanea Franciscana, n. 74, p. 111-145, 2004.

. Estudio Preliminar. In: JACA, F. J. Resolución sobre la libertad de los negros, en estado de paganos y después ya cristianos. Madrid: CSIC, 2002. p. XXI-XCVIII.

. Estudio Preliminar. In: MOIRANS, E. Siervos Libres. Madrid: CSIC, 2007. p. XV-LXXV.

. Francisco José de Jaca: una vida a favor de la liberación de los esclavos negros. Collectanea Franciscana, n. 72, p. 599-671, 2002.

HANKE, L. The Spanish Struggle for Justice in the Conquest of America. Philadelphia: University of Pennsylvania Press, 1949.

HÖFFNER, J. La Ética Colonial Española del Siglo de Oro. Madrid: Cultura Hispánica, 1957.

ISIDORUS HISPALENSIS EPISCOPI. Etymologiarum sive Originum. Ed. W. M. Lindsay. Oxonii: E Typographeo Clarendoniano, 1911. v.1.

IUSTINIANUS IMPERATOR. Corpus Iuris Civilis. Ed. P. Krueger, T. Mommsen. Berolini: Weidmannos, 1889. v.1.

JACA, F. J. Resolución sobre la libertad de los negros, en estado de paganos y después ya cristianos. Ed. M. González. Madrid: CSIC, 2002. (CHP II, v.11)

JOSAPHAT, C. Las Casas: Todos os direitos para todos. São Paulo: Loyola, 2000.

LAS CASAS, B. Historia de las Indias. Madrid: Miguel Ginesta, 1875. 3t.

MAURICIO, D. A Universidade de Évora e a Escravatura. Didaskalia, n.7, p. 153200, 1977.

MERCADO, T. Summa de tratos y contratos. Sevilla: Hernando Diaz, 1571.

MOIRANS, E. Siervos Libres: Una propuesta antiesclavista a finales del siglo XVII. Ed. M. González. Madrid: CSIC, 2007. (CHP II, v. 14)

. Siervos Libres. In: GARCÍA, J. Dos Defensores de los Esclavos Negros en el Siglo XVII. Maracaibo: Biblioteca Corpozulia; Caracas: Universidad Católica Andrés Bello, 1982. p. 179-298. 
MOLINA, L. De iustitia et iure. Coloniae Allobrogun: Marci Michaelis Bousquet, 1733.

NUCCETELLI, S.; SCHUTTE, O.; BUENO, O. (Eds.). A Companion to Latin American Philosophy. Chichester: Wiley-Blackwell, 2010.

OLIVEIRA, F. Arte da guerra do mar. Coimbra: Iohão Aluerez, 1555.

PAGDEN, A. The Fall of Natural Man. Cambridge: CUP, 1986.

PICH, R. Alonso de Sandoval and the Ideology of Black Slavery. Patristica et Mediaevalia, n. 36, p. 51-74, 2015.

PICH, R.; CULLETON, A.; STORCK, A. (Eds.). Patristica et Mediaevalia, Buenos Aires, n. 36, 2015.

REBELLO, F. Opus de obligationibus iustitiae, religionis et caritatis. Lugduni: Horatii Cardon, 1608.

SANCHEZ, T. Consilia seu opuscula moralia. Lugduni: Iacobi Prost, 1634.

SANDOVAL, A. De instauranda Aethiopum salute: El mundo de la esclavitud negra en América. Ed. A. Valtierra. Bogotá: Biblioteca de la Presidencia de Colombia, 1956. . Un tratado sobre la esclavitud. Ed. E. Vilar. Madrid: Alianza, 1987. . De instauranda Æthiopum salute. Madrid: s.n., 1647.

SOTO, D. De iustitia et iure. Salmanticae: Andreas a Portonariis, 1553.

SARANYANA, J. La Filosofía Medieval. Pamplona: EUNSA, 2003.

SARANYANA, J. (Dir.). Teología en América Latina. Volumen II/1. Madrid: Iberoamericana; Frankfurt: Vervuert, 2005.

SOLÓRZANO Y PEREIRA, J. De Indiarum Iure. Liber I. Ed. C. Baciero et alli. Madrid: CSIC, 2001. (CHP II, v. 8)

SOUZA, J. Las Casas, Alonso de Sandoval e a defesa da escravidão negra. Topoi, v. 7, n. 12, p. 25-59, 2006.

THOMAS, H. The Slave Trade. New York: Simon \& Schuster, 1997.

VILAR, E. La postura de la Iglesia frente a la esclavitud. Siglos XVI y XVII. In: SOLANO, F.; GUIMERÁ, A. (Eds.). Esclavitud y Derechos Humanos. Madrid: CSIC, 1986.

VITORIA, F. Political Writings. Ed. A. Pagden, J. Lawrence. Cambridge: CUP, 1991. ZAVALA, S. Por la senda hispana de la libertad. 2.ed. México-DF: Fondo de Cultura Económica, 1993.

Endereço do Autor:

Av. Carlos Gilberto Weis, n.155

Bairro Quatro Colônias

93804-870 Sapiranga - RS

fernandodoca@ifsul.edu.br 